Ira Österberg

\section{MUSIIKKI JA KERRONNAN TASOT KIRILL SEREBRENNIKOVIN ELOKUVASSA KESÄ}

Tässä artikkelissa analysoin tuoreen venäläisen rock-elokuvan, Kirill Serebrennikovin ohjaaman Kesän (Leto, Venäjä 2018) musiikinkäyttöä. Tarkastelun kohteena on toisaalta se, mitä musiikkia ja mitä kappaleita elokuvassa kuullaan, mutta myös se, miten ne kuullaan: miten ne suhteutuvat kerronnan tasoihin ja minkälaisia konteksteja musiikkikatkelmat elokuvassa saavat. Elokuvan musiikin formalistis-narratologiseen rakenneanalyysiin pohjautuvan lähiluvun jälkeen tarkastelen sitä, miten Kesän musiikinkäytön strategiat asettuvat venäläisten elokuvien rock-musiikinkäytön konventioiden kontekstiin.

\section{Johdanto}

Viime vuonna ilmestynyt Kesä (Leto, Venäjä 2018) on venäläinen rock-elokuva, joka on saanut poikkeuksellisen paljon huomiota lännessä. Suurin kohu ei ole liittynyt niinkään itse elokuvaan, vaan ohjaaja Kirill Serebrennikovin saamaan kotiarestiin häneen kohdistuvien talousrikossyytösten vuoksi - seikka, joka on nostettu esille lähes kaikissa elokuvan arvosteluissa (ks. esim. Virtanen 2018; Beumers 2018; Safariants 2018). Ehkä osittain juuri tämän kuohunnan vuoksi Kesä on pitkästä aikaa ensimmäinen venäläinen näytelmäelokuva, joka on otettu elokuvateatterilevitykseen myös Suomessa.

Cannesin elokuvajuhlilla Kesä voitti palkinnot parhaasta naispääosasta ja parhaasta soundtrackista. Se on ensimmäinen tällä palkinnolla palkittu elokuva, jonka musiikkistrategia ei pohjaa alkuperäissävellykseen, vaan jonka pääpaino on jo olemassa olevien laulujen kompilaatiolla. ${ }^{1}$ Elokuvan musiikki sai osakseen myös negatiivista huomiota jo kauan ennen elokuvan julkaisua. Kesä nimittäin kertoo avoimen fiktiivisin keinoin kahdesta neuvostoajan todellisesta rock-tähdestä, Zoopark-yhtyeen keulahahmosta Mihail "Majk" Naumenkosta ja Kino-yhtyeen Viktor Tsoista. Elokuvan sangen eidokumentaarinen lähestymistapa Venäjällä lähestulkoon pyhänä koettuun pop-kulttuurin aineistoon sai jyrkän tuomion monelta aikalaishahmolta: elokuvan katsottiin vääristelevän sitä, mitä todella tapahtui (Safariants 2018).

Kesän kuvaaman aikakauden, 1980-luvun alun, legendaariset tapahtumat ja toisaalta myös nykyinen maailmanpoliittinen ilmapiiri ovat siten

Ira Österberg, FT, Aleksanteriinstituutti

1 Palkintoa on jaettu vasta vuodesta 2013. Palkinnon saivat Zveri-yhtyeen solisti Roma "Zver" Byluk ja kitaristi German Osipov. Zveri-yhtye vastaakin elokuvan useimmista cover-versiosovituksista, Osipov myös elokuvan ainoasta alkuperäismusiikista eli kitaraimprovisaatiokatkelmista. Elokuvan musiikin tuottajaksi elokuvan lopputekstit nimeävät kuitenkin A. Sevidovin (yhtyeestä Tesla Boy), joka on sovittanut elokuvan musikaalinumeroiden kappaleet. Elokuvan soundtrack-levyn mainos Zveri-yhtyeen nettisivuilla puolestaan julistaa musiikin tuottajiksi juuri Bylukin ja Osipovin (<https://zve.ru/news/ premera-vykhod-ost-leto/>, linkki tarkistettu 8.3.2019). 
pääsääntöisesti vieneet huomion pois sen tarkastelusta, minkälainen Kesä on elokuvana: minkälaisin elokuvallisin keinoin elokuvan tarina kerrotaan. Kuvaavaa on se, että samoihin aikoihin Kesä-elokuvan kanssa ensi-illan sai myös Serebrennikovin ohjaama dokumentti Posle leta ["Kesän jälkeen"]. Dokumentissa Kesä-elokuvan näyttelijä Aleksandr Kuznetsov haastattelee henkilöhahmojen todellisia esikuvia, mm. edesmenneen muusikko Naumenkon vaimoa, Natalija Naumenkoa, jonka muistelmiin elokuva päällisin puolin ilmoittaa pohjautuvansa. Kun on kyse tosielämän muusikoiden kuvauksesta, artistien todellinen elämänkaari ja kokonaistuotanto vievät helposti huomion elokuvan kuvaamista tapahtumista fiktiivisenä rakenteena ja elokuvan sisältämästä musiikista elokuvamusiikkina. Elokuvan intertekstuaaliset, tekstin sisältä ulospäin viittaavat kytkökset ovat niin runsaita, että elokuva elokuvana unohtuu. Mutta mille Kesä-elokuvan musiikkistrategia oikeastaan rakentuu?

Tässä artikkelissa pyrin tarkastelemaan Kesä-elokuvan musiikkia elokuvamusiikkina. Käytännössä tämä tarkoittaa elokuvassa käytetyn musiikin formalistista rakenneanalyysia. Huomion kohteena ei ole vain se, minkälaista musiikkia elokuvassa kuullaan, vaan myös se, miten musiikki kohtauksien rakenteeseen sijoittuu: miltä kerronnan tasolta sen voi katsoa kuuluvan ja minkälaisissa konteksteissa se esiintyy. Tässä tarkastelussa keskeiseksi nousee klassinen narratologinen jaottelu diegeettisen ja ei-diegeettisen musiikin välillä (Gorbman 1987, 3; Heldt 2013, 48-49), mutta myös ekstrafiktiivisyys (extrafictionality, Heldt 2013, 23-27) ja supradiegeettisyys (Altman 1987, 62-85; Heldt 2013, 106-107, 137-138). Laajempaa tutkimuksellista kontekstia tuo Juri Tynjanovin klassinen formalistinen näkemys taidekeinojen evoluutiosta (2001 [1927]).

Esitän seuraavaksi tarkemman katsauksen analyysini teoriataustaan ja metodologiaan, jotka toimivat myös tutkimukseni kysymyksenasettelun motivaattoreina. Sitten esittelen Kesä-elokuvassa käytetyn musiikin yleiset piirteet, jonka jälkeen paneudun erillisissä alaluvuissa analysoimaan musiikin läsnäoloa ensin elokuvan diegesiksen sisällä ja sitten sen ulkopuolella. Artikkelin lopuksi pyrin hahmottamaan, miten Kesän musiikkistrategia sijoittuu venäläisen elokuvan rock-musiikin käytön konventioiden kontekstiin.

\section{Rock-musiikki elokuvan rakenne-elementtinä ja taiteen evoluutio}

Rock-musiikin rooli neuvostokulttuurissa on saanut sekä tieteellistä että eitieteellistä huomiota osakseen aina perestroikasta ja Neuvostoliiton romahtamisesta lähtien (esim. Ryback 1990; Troitski 1991; Cushman 1995; Risch 2015). Musiikkiin keskittyvät tutkimukset eivät kuitenkaan lähes koskaan viittaa elokuviin ja rock-musiikin elokuvalliseen käyttöön. Elokuvatutkimuksen ja elokuvamusiikintutkimuksen puolella 1980-luvun lopun Neuvostoliiton underground-rockin esiinmarssiin vahvasti liittyneet nuorisoelokuvat - erityisesti Murto yössä (Vzlomshtshik, 1986), Assa (1987), Piikki (Igla, 1988) nostetaan kuitenkin varovaisesti esille (esim. Egorova 1997, 277-278; Lawton 1992, 187). Näissä tutkimuksissa ei kuitenkaan tarkastella juuri lainkaan sitä, miten musiikkia on näissä elokuvissa käytetty. Usein tyydytään toteamaan, että elokuvissa on paljon rock-musiikkia ja että muusikot esiintyvät elokuvissa myös itse. Se, että eri elokuvien rock-musiikin käytössä voisi olla jonkinlaista laadullista ja rakenteellista eroa eri aikakausina ja eri genreissä, ei huomioida ollenkaan. Tämä on kuitenkin tärkeä seikka: sama kappale voi toimia hyvinkin erilaisissa funktioissa riippuen elokuvan tyylilajista, kappaleen suhteesta 
elokuvan kokonaismusiikkistrategiaan ja siitä kerronnallisesta positiosta, johon se asemoidaan.

Olen pyrkinyt paikkaamaan tätä tutkimuksellista aukkoa väitöskirjassani (Österberg 2018), jossa analysoin Aleksei Balabanovin Veli-elokuvan (Brat, Venäjä, 1997) rock-musiikinkäyttöä pyrkien suhteuttamaan sitä neuvostoelokuvan musiikkistrategioiden perinteeseen. Keskeinen argumenttini on, että rock-musiikin käytössä neuvostoaikana ja juuri Neuvostoliiton jälkeen voidaan havaita siirtymä diegeettisestä kuriositeetista ei-diegeettiseksi kerronnan välineeksi. Samalla tapahtuu irtautuminen rock-musiikista ja nuorisosta aiheena laajempaan skaalaan kerronnan aiheissa. Rock-musiikki esiintyy alun perin nuorison tanssikohtausten taustalla diegeettisenä poikkeamana, ja vaikka perestroika-aikaan rock-lauluista tuleekin koko elokuvan kattava musiikillinen idiomi, elokuvien tarinat pitäytyvät edelleen nuorisoaihelmissa ja kappaleet kuullaan pääosin diegeettisinä konserttiesityksinä. Balabanovin Veli on ensimmäinen venäläinen elokuva, jonka musiikki perustui täysin olemassa olevien rock-kappaleiden kompilaatioon, ja samalla elokuva pyrki tekemään hienovaraista pesäeroa nuorisoaihelmaan irtautumatta siitä kuitenkaan täysin.

Tässä artikkelissa sovellan väitöskirjatutkimustani varten kehittämääni metodologiaa, jonka tarkoituksena on ollut luoda välineistöä elokuvamusiikinkäytön analysoimiseksi vertailukelpoisella tavalla. Tarkastelun taustalla on klassinen formalistinen taidekäsitys ja erityisesti Juri Tynjanovin ajatus taidekeinojen evoluutiosta (2001 [1927]). ${ }^{2}$ Formalistisen taidekäsityksen keskiössä on ajatus taideteoksesta rakenteena, jossa jokaisella elementillä on funktio - merkitys, joka määräytyy vain suhteessa kokonaisrakenteeseen (Tynjanov 2001 [1927], 268). Taiteen evoluutio muodostuu Tynjanovin mukaan yksittäisten taiteen lajien esittämisen konventioiden muutoksesta: säilyttääkseen ilmaisuvoimansa kivettyneitä konventioita vastaan, taiteen täytyy löytää koko ajan uusia tapoja yhdistää elementtejä ja niiden funktioita (Tynjanov 2001 [1927], 269-270). Jotta voidaan selvittää, mitä teos merkitsee, on ensin selvitettävä, miten se on rakennettu, eli mikä on sen yksittäisten elementtien funktio suhteessa kokonaisuuteen. Tämä on se seikka, joka erottaa yksittäisen taideteoksen muista vastaavista, ja toisaalta myös ympäröivästä tavallisesta maailmasta, eli "ei-taiteesta". Keskeistä formalistiselle metodille on juuri ajatus teoksen itsenäisyydestä suhteessa ympäröivään maailmaan, mutta myös tekijään ja tekijän intentioon (2001 [1927], 266, 274-275).

Metodologinen lähestymistapani tämän artikkelin analyysissa on formalistinen lähiluku, jossa yllämainittuihin perusprinsiippeihin nojaten hyödynnän yksittäisen elokuvan musiikin analyysiin erityisesti elokuvamusiikintutkimuksen narratologista suuntausta. Elokuvamusiikin narratologialle perustan on luonut Claudia Gorbmanin (1987) pioneerityö ja suuntauksen on elvyttänyt erityisesti Guido Heldtin (2013) kattava ja analyyttinen päivitys aiheesta. Klassinen narratologinen jaottelu diegeettisen ja ei-diegeettisen musiikin välillä (Gorbman 1987, 3; Heldt 2013, 48-49) toimii hyvin myös formalistisen analyysin lähtökohtana: miten musiikki positioidaan suhteessa kerronnan tasoihin määrittää myös sen, korostaako musiikki itse itseään elokuvan aiheena/teemana vai käytetäänkö musiikkia elokuvan kerronnan välineenä ilmentämään jotain muuta aihetta/teemaa. Käytännössä siis suhde kerronnan tasoon määrittää yksittäisen elementin saamat funktiot - tai ainakin sen, mitkä funktiot yksittäisissä tapauksissa korostuvat.

Koska Kesä-elokuvan musiikki käytännössä suhteutuu kerrontaan monipuolisesti ja moniulotteisesti, diegettisen ja ei-diegeettisen tason jakoa on hyödyllistä laajentaa kahdella erikoistapauksella. Heldt puhuu ekstrafiktiivi-
2 Tynjanovin alkuperäinen artikkeli "O literaturnoi evoljutsii" (1927) on luettavissa osoitteessa: <philologos.narod. ru/tynyanov/pilk/poet5.htm> (Linkki tarkistettu 31.5.2019). 
syydestä (extrafictionality, 2013, 23-27) kuvatessaan tapaa, jolla alkutekstien (ja miksei lopputekstienkin) kerronta, kuvasto ja musiikki suhteutuvat elokuvan varsinaiseen rakenteeseen - ne sijaitsevat ikään kuin diegeettinen-ei-diegeettinen-akselin ulkopuolella. Lisäksi analyysissa olennaiseksi muodostuu myös Rick Altmanin $(1987,62-85)$ lanseeraama ja Heldtin $(2013,106-107,137-138)$ tehokkaasti soveltama supradiegeettisyys, joka liittyy tapaan, jolla erityisesti musikaalielokuvat positioivat fantastiset laulunumeronsa suhteessa muuhun kerrontaan.

Artikkelin tavoite on tuottaa tietoa Kesä-elokuvan musiikin käytön lainalaisuuksista eli musiikin rakenteellisesta distribuutiosta. Ensin pyrin kartoittamaan mitä musiikkia elokuvasta löytyy, seuraava vaihe on tarkastella, miten nämä musiikkikappaleet sijoittuvat elokuvan kerronnan eri tasoille ja onko tässä havaittavissa lainalaisuuksia. Havaitut lainalaisuudet musiikkityyppien ja kerronnan rakenteeseen sijoittumisen kanssa, eli elokuvan musiikin rakenteellinen distribuutio, muodostaa elokuvan musiikillisen strategian. Rakenneanalyysin ohella nostan esiin esimerkkejä ja mahdollisia suuntia tulkinnalle, joita tulosten pohjalta on mahdollista tehdä. Mutta valitusta metodologisesta tutkimuskehikosta johtuen, ja myös koska tutkimusartikkeli on varsin rajattu ilmaisumuoto, tarkastelun ulkopuolelle jäävät tässä artikkelissa elokuvan sisällön käsittely tarinana (sen fabula), elokuvan rakenteen muiden elementtien (esim. kuvauksen, leikkauksen, näyttelijätyöskentelyn) laajemmat lainalaisuudet, mahdolliset pohdinnat tekijän intentiosta tai poliittisesta agendasta, sekä kaikki ne mahdolliset tulkinnat, joita "musiikki" elokuvan tarinan aiheena kirvoittaa, mukaan lukien rock-musiikki laajempana kulttuurisena ilmiönä.

Artikkelissa esittämäni analyysin tulokset ja siinä käyttämäni metodologia osoittavat toivoakseni formalistisen ja narratologisen metodin hedelmällisyyden elokuvamusiikin tutkimuksessa sekä antavat toivottavasti myös inspiraatiota mahdolliseen jatkotutkimukseen Kesä-elokuvan musiikinkäytön mahdollisista tulkinnoista erilaisissa konteksteissa.

\section{Kesän fiktiivinen musiikkimaisema ja miesten rock}

Kesä on tarina Neuvostoliiton underground-rockin noususta mainstreamiin 1980-luvun alussa. Tarinan päähenkilöt ovat oikeita, tosielämän rock-tähtiä, Majk Naumenko (1955-1991) ja Viktor Tsoi (1962-1990). Elokuva kertoo siitä, miten etabloitunut underground-tähti Naumenko ottaa siipiensä suojaan nuoren Tsoin, ja vaimonsa Natalja Naumenkon kanssa he luotsaavat tulevan rock-legendan yhtyeineen ensimmäiselle keikalle, levytysstudioon ja lopulta suuren yleisön tietoisuuteen. Tämän musiikillisen kehityskaaren ohella luodaan myös pienimuotoinen romanttinen kolmiodraama päähenkilöiden välille.

Vaikka elokuva on päällisin puolin elokuva neuvostorockista, vain alle puolet elokuvassa kuultavista musiikkikatkelmista on jollain tavoin määriteltävissä neuvostorockiksi. Elokuvan musiikkiraita on itse asiassa monipuolinen yhdistelmä sekä neuvostoliittolaisia että länsimaisia rock- ja pop-lauluja, ja lisäksi siinä kuullaan myös elokuvaa varten sävellettyä (improvisoitua) instrumentaalista kitaramusiikkia. Kaiken kaikkiaan elokuva sisältää 42 musiikkikatkelmaa, joiden yhteiskesto on 76 minuuttia, mikä tekee noin $60 \%$ elokuvan kokonaiskestosta (2 tuntia 3 minuuttia). ${ }^{3}$

Elokuvassa kuullaan yhteensä 33 eri laulua tai laulukatkelmaa. Niistä 27 on venäjän- tai englanninkielisiä rock-kappaleita, neljä edustaa neuvostoiskelmää
3 Luku on varsin korkea kun sitä vertaa Juraj Lexmannin $(2006,158)$ arvioon, että keskivertoelokuvasta noin kolmasosan taustalla kuullaan musiikkia. On tosin huomattava, että Lexmann ei kerro, minkälaiseen dataan tämä arvio perustuu. Joka tapauksessa musiikin runsas läsnäolo Kesässä kertoo ainakin sen, että kyseessä tosiaan on musiikkielokuva (= elokuva musiikista), ei ainoastaan elokuva, jossa on musiikkia. 


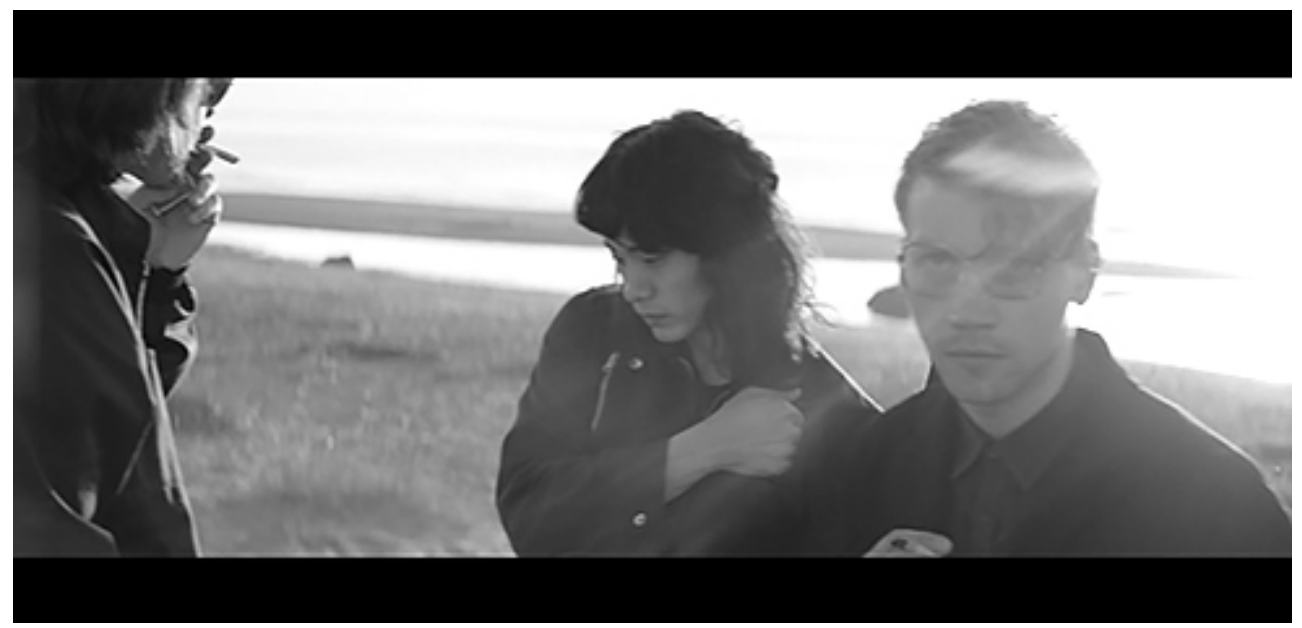

4 Zooparkin ja Naumenkon tuotannosta nämä viisi edustavat ehkä juuri niitä tunnetuimpia lauluja. "Sladkaja N" ja "Drjan" ovat Majk Naumenkon ensimmäiseltä levyltä Sladkaja N i drugije (1980), "Zvezda rok-n-rolla" puolestaan sisältyy ensimmäiseen Zooparkin nimellä julkaistuun levyyn, Blues de Moscou, joka on konserttitaltiointi vuodelta 1981. Majkin toinen soololevy LV (1982) puolestaan sisältää laulut "Leto" ja "6 utra".

Kohtaaminen rannalla: Majk Naumenko (Roman Bilyk), Viktor Tsoi (Teo Yoo) ja Skeptikko (Aleksandr Kuznetsov). Kuva: Kaappaus DVD:Itä.

eli estradaa, lisäksi kuullaan yksi neuvostobardin kappale sekä fragmentti Neuvostoliiton kansallishymnistä. Kappaleet ovat siten pääasiassa jo olemassa olevia, autenttisia 1980-luvun alun lauluja, mikä korostaa pyrkimystä muodostaa realistinen kuvaus tietyn aikakauden miljööstä, ihmisistä ja tapahtumista. Tietynlaista dokumentaarista otetta luo myös elokuvan varsinaisen tarinamaailman mustavalkoisuus.

Autenttisuustendenssi näyttäytyy kuitenkin toisenlaisessa valossa, kun ottaa huomioon, että suurin osa - yhteensä 21 - lauluista kuullaan tätä elokuvaa varten sovitettuina uudelleentulkintoina. Tämä tuo niiden merkitykseen mukaan lisäkerroksen, joka korostaa esitetyn ehdollisuutta. Se muistuttaa enemmän tai vähemmän hienovaraisesti, että kyse ei kuitenkaan ole dokumentista, vaan fiktiivisestä, nykyhetkestä käsin luodusta katseesta menneeseen.

Elokuvan musiikkiraita rakentuu vahvasti Naumenkon luotsaaman Zoopark-yhtyeen ja Tsoin Kino-yhtyeen repertoaareille - siitä huolimatta, että vain puolet elokuvassa enemmän tai vähemmän kuulluista lauluista (16 laulua 33:sta) edustaa heidän tuotantoaan. Zooparkilta ja Naumenkolta kuullaan yhteensä vain viisi kappaletta: "Drjan" ["Lumppu"], "Leto" ["Kesä"], "Moja sladkaja N" ["Suloinen N"], "Zvezda rok'n'rolla" ["Rock'n'roll-tähti], "6 utra" ["Aamulla klo 6"]. ${ }^{4}$ Niiden keskeisyyttä korostaa kuitenkin se, että neljä viidestä kuullaan lähestulkoon kokonaisuudessaan erityisinä musiikkiesityksinä ja että "Drjan" toimii peräti koko elokuvan avauskappaleena. Naumenkon näkökulman nostaa ensisijaisen tärkeäksi tietenkin myös se, että juuri hänen kappaleensa "Leto" on valittu koko elokuvan nimeksi.

Kesä-elokuvassa Zooparkin kappaleet esittää todellinen venäläinen nykypäivän rock-bändi Zveri ["Eläimet"]. Zveri on sen laulusolistin Roman Bilykin (Roma Zver) ympärille vuonna 2001 koottu, sangen pitkäikäinen rock-yhtye, joka levyttää edelleen ja on mm. valittu yhdeksän kertaa Venäjän MTV:n parhaaksi rock-yhtyeeksi. Roma Zver myös esittää elokuvassa Naumenkoa ja laulaa siis itse kappaleet. Elokuvan maailmassa nämä kaksi yhtyettä, Zoopark ja Zveri - siis "eläintarha" ja "eläimet" - sulautuvat yhteen ja kaksi eri aikatasoa kohtaavat.

Naumenkon kirjoittamien laulujen itsereflektiiviset tekstit toimivat elokuvan kontekstissa sekä esittäjänsä että ylipäänsä neuvostorock-skenen 
luonnehtijoina, mutta kommentoivat myös elokuvan sisäistä narratiivia hienovaraisemminkin. "Leto"-kappaleen alaotsikko on alunperin "Pesnja dlja Tsoja" ["Laulu Tsoille"], sillä se on Naumenkon tekemä parodia Viktor Tsoin tyylistä ja lyriikoista - siis huumorikappale. Laulun mukanaolo on mahdollisesti elokuvan ainoa varsinainen musiikillinen anakronismi: elokuvan tarinamaailmassa se on olemassa jo ennen kuin Majk kuulee Tsoista ensimmäisen kerran.

Mielenkiintoista Zoopark-tekstien valinnassa on se, miten peräti kahdessa laulussa käsitellään naisten seksuaalisuutta negatiivisessa valossa. Neuvostorockin misogynistisimmäksi tekstiksi mainittu (Semeljak 2018, 6) "Drjan" kertoo kelvottomasta naisesta, joka makaa kaikkien kanssa, ja on ehkä hieman yllättävä valinta aloituskappaleeksi elokuvaan, joka pohjaa (ainakin näennäisesti) naisen muistelmiin. Myös "Moja sladkaja N" käsittelee naisen kevytkenkäisyyttä ja useat kriitikot ovatkin nähneet kappaleen sanojen viittaavan elokuvan kuvaamaan Natalija Naumenkon ja Viktor Tsoin väliseen suhteeseen (Safariants 2018; Ryabchikova 2018) - siitäkin huolimatta, että elokuvassa tekstistä kuullaan vain aivan pieni katkelma.

Kino-yhtyeeltä kuullaan yhteensä yksitoista kappaletta. Elokuva kuvaa heidän ensimmäisen albuminsa 45 (1982) levytykseen johtavia tapahtumia, ja elokuvassa kuullut kappaleet ovatkin todenmukaisesti pääosin tältä levyltä. Vain kaksi kappaletta muodostaa poikkeuksen: "Mojo nastroenije" ["Minun mielialani"] ei päätynyt levylle, mutta on tallennettu kotikonserttinauhoitteisiin suunnilleen samalta aikakaudelta. "Kontšitsja leto" ["Kesä loppuu"] on yhtyeen viimeiseltä, Viktor Tsoin kuoleman jälkeen postuumisti julkaistulta Tšornyi albomilta ("Musta albumi", 1991). Laulu kuullaan lopputekstien aikana, joten se on selkeästi erotettu elokuvan tarinasisällöstä. Se on ainoa Kinon alkuperäisesityksenä kuultu kappale ja samalla ainoa kappale, joka ei kuulu 1980-luvun alun äänimaisemaan. Valintaan on vaikuttanut tietenkin laulun nimi - implisiittisen tekijän ironinen kommentaari: nyt tämä elokuva (ja sen kuvaama kesä) päättyy.

Siinä missä Naumenkon tekstit näyttäytyvät neuvostokontekstissa aihelmiltaan ja sanastoltaan radikaaleilta (seksi, abortit, juopottelu, rock-tähteys) ja nojaavat pääosin kansainväliselle rock-kulttuurille tyypillisiin ilmiöihin eli kontekstisidonnaisiin reaalioihin (esim. lumput, bändärit, kitaranrikkomiset), Tsoin tekstit puolestaan perustuvat pieniin arjen havaintoihin. Hän keskittyykin käsittelemään juuri neuvostokontekstia ja sen omia reaalioita näkökulmalla, jossa pienet yksityiskohdat kasvavat suuriksi eksistentiaalisiksi kysymyksiksi. Sanastoltaan tekstit ovat rajattuja ja niissä paljon toistoa, ja juuri toiston voima luo merkityksellisyyttä ja uutta näkökulmaa kuluneisiinkin fraaseihin ja käsitteisiin. Tsoin voi ajatella olevan venäläisen rockin suuri naivisti, mikä helposti sekoittuu ironiaan ja huumoriin, mutta pohjimmiltaan tekstit ovat aika vakavia. Kesä-elokuvan kontekstissa Kinon laulujen tekstisisältö leijuu pääosin ikään kuin omassa sfäärissään, irrallisena elokuvan tarinankerronnasta. Loppukappaleen lisäksi elokuvan tarinaa kommentoivana tekstinä voi nähdä oikeastaan vain elokuvan viimeiseen konserttiesitykseen sisältyvän "Derevo"-kappaleen ["Puu"]. Laulun tekstin ("Minä istutin puun") voi nähdä viittaavan elokuvan alkupuolen kohtaukseen, jossa nuoria rokkareita syytetään tyhjäntoimittamisesta: "Teidän tulisi perustaa perhe, rakentaa koti - tai istuttaa puu!"

Kolmas elokuvallisen representaation ja musiikillisen uudelleentulkinnan saanut suuri neuvostorokkari on Andrei Panov eli artistinimeltään Svinja ["Sika"], johon Kesässä tosin viitataan vain nimellä Punkkari. Panov oli 
Avtomatitšeskije udovletvoriteli -yhtyeensä ["Automaattiset tyydyttäjät"] kanssa Neuvostoliiton johtavia punk-liikkeen edustajia. Vaikka henkilöhahmo onkin elokuvassa mukana keskeisesti alusta loppuun, hänen repertoaaristaan kuullaan vain yksi kappale, eroottisesti hekumoiva "Vsetselo" ["Kokonaan"], jonka esittää näyttelijä Aleksandr Gortšilin.

Koska suurin osa kuulluista kappaleista on uudelleensovitettu elokuvaa varten, elokuvan musiikkiraita sisältää vain muutaman venäläisen alkuperäisesityksen. Kinon "Kontšitsja leton" lisäksi alkuperäistä neuvostorockia kuullaan vain yhden katkelman verran: Strannyje igry -yhtyeen ["Kummat leikit"] "Da da" erottuu juuri ja juuri elokuvan alkupuolen kohtauksen taustalla (0:05:48). Tämän lisäksi kuullaan näyte möreä-äänistä bardia, Arkadi Severnyiä, sekä peräti neljää estradaksi eli neuvostoajan iskelmäksi luokiteltavaa kappaletta. Näistä keskeisimmän roolin saavat diskoiskelmä "Ne obeštšai" ["Älä lupaile"] vuodelta 1980, jonka esittää lauluorkesteri Zdravstvui, pesnja! ["Tervehdys laululle!"], sekä laulajatähti Sofia Rotarun Tšervona ruta -yhtyeensä ["Punainen ruuta"] kanssa moldaviaksi esittämä "Ver mne" ("Usko minua", 1981).

Kokonaisuudessaan elokuvassa kuullun musiikin kenttä on hyvin miehinen. Naiset yksittäisinä taustaääninä edustavat vain valtavirtaa, monella tapaa alempiarvoiseksi katsottavaa viihdemusiikkia. Henkilöhahmoina keskeisiä ovat artistien vaimot - Natalja Naumenko ja loppupuolella Marianna Tsoi - mutta heidän roolinsa on olla muusikoiden tukijoita ja mahdollistajia, ei itse musiikintekijöitä. Esitetyn musiikin miehisyys on mielenkiintoista, kun ottaa huomioon, että pohjana on Nataljan kirja; hän on se prisma, jonka kautta näitä miehiä ja näitä muusikoita tarkkaillaan, mutta naispositio ei kuulu lainkaan musiikissa. Toisaalta tämän voi ajatella olevan sangen realistinen representaatio neuvostorockin sukupuolijakaumasta (ks. esim. Troitski 1991, 113; Cushman 1995, 184-185). ${ }^{5}$

Ulkomainen eli läntinen ja käytännössä siis englanninkielinen rock on puolestaan elokuvassa edustettuna peräti yhdeksän kappaleen verran. Näistä kaikkiaan viisi on alkuperäisesityksiä: Velvet Undergroundin "I'm Waiting for the Man" (1967), David Bowien "Ashes to Ashes" (1980) sekä peräti kolme kappaletta brittiläiseltä T-Rex-yhtyeeltä: "Broken Hearted Blues" (1973), "Children of the Revolution" (1972), sekä "20th Century Boy" (1973). Ulko-

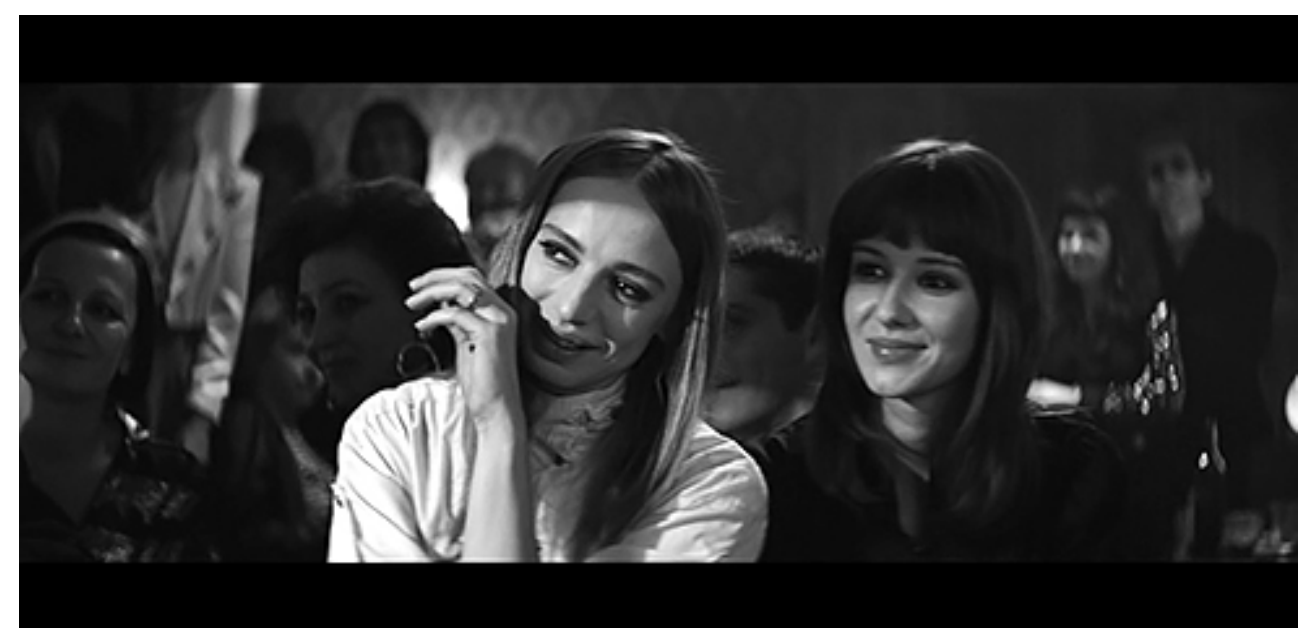

Miestensä managerit: Marianna Tsoi (Julija Loboda) ja Natalja Naumenko (Irina Staršenbaum). Kuva: Kaappaus DVD:Itä.
5 Erityisesti sosiologi Thomas Cushman $(1995,184)$ tekee mielenkiintoisen huomion juuri siitä, miten venäläisen rockin miehisyyden keskellä naisten rooli varsin usein on toimia managerina ja asioiden järjestäjänä. 
maiset artistit edustavat kuvatun aikakauden vaihtoehtoista äänimaisemaa, niitä artisteja, joita neuvostorokkarit itse kuuntelivat - ainakin tämän elokuvan tarinamaailmassa.

Kaikkein mielenkiintoisimpana elokuvan musiikkivalikoimassa näyttäytyy kuitenkin venäläisen näyttelijäkaartin ja artistien uudelleentulkitsemat versiot englanninkielisistä rock-klassikoista. Innovatiivisen käsittelyn saavat Talking Headsin (1977) "Psycho Killer", Iggy Popin (1977) "The Passenger" ja Lou Reedin (1972) "Perfect Day". Näissä versioissa uudelleentulkinnallinen ote on huomattavasti vapaampi kuin venäläisissä rock-versioissa, jotka pyrkivät esittämään Kinoa ja Zooparkia "ikään kuin" alkuperäisinä. Näiden laulujen englanninkieliset tekstit lausutaan vahvasti venäläisellä aksentilla ja lauletaan pääosin venäläisten näyttelijöiden amatöörimäisillä lauluäänillä. Kaikkein suurimman transformaation käy läpi David Bowien kirjoittama ja Mott the Hoople -yhtyeen alunperin vuonna 1972 esittämä "All the Young Dudes". Tämän kappaleen cover-version eivät esitä elokuvan näyttelijät vaan oikea, nykypäivän postpunk-elektro-avantgarde-yhtye, siperialais-pietarilainen Shortparis.

Kaikkein kaikkiaan elokuvassa kuultava musiikkivalikoima luo realistisen tietyn aikakauden ja kulttuurikontekstin musiikkimaiseman. Kuullun musiikin pohjalta muodostuu selkeä käsitys kolmen eri tason musiikkikulttuurista: epävirallinen neuvostorock - valtavirran viihdemusiikki - ulkomainen rock. Elokuvaa varten tehdyt olemassa olevien kappaleiden uudelleen tulkinnat sekä vahvistavat autenttisuutta (Kino, Zoopark) että purkavat sitä (ulkomaiset esitykset). Tämän lisäksi raja elokuvaa varten sävelletyn ja olemassa olevan musiikin välillä liudentuu hieman: useimmat lauluista on sovitettu uudelleen elokuvaa varten, elokuvan näyttelijät laulavat ne ja sama kitaristi soittaa kaikissa. Mutta tärkeä rooli elokuvan merkityksenluonnissa ei ole pelkästään sillä mitä musiikkia elokuvassa kuullaan, vaan myös sillä minkälaisen paikan se elokuvassa saa eli miten se positioidaan suhteessa diegesikseen. Lisäksi on huomioitava, että musiikki voi olla läsnä elokuvassa monella muullakin tapaa kuin korvin kuultavana musiikkina.

\section{Laulut ja musiikki diegesiksessä}

Diegeettisesti esitetyt laulut kuuluvat melko itsestään selvästi musiikkiaiheisen elokuvan musiikkistrategiaan. Jos elokuvan aiheena on muusikkous, muusikot ja heidän elämänsä, sekä musiikin tekeminen, on luonnollista että lauluja ja musiikkia esitetään tarinamaailman sisältä käsin. Näin diegeettiset musiikkikatkelmat ankkuroivat elokuvan realismiin: esitellään mahdollisimman autenttinen aikakauden äänimiljöö, niin konserttiesitysten kuin muiden äänilähteiden osaltakin. Tällaisissa paikoissa - treenikämpät, rock-klubin lava ja äänitysstudio - voi todellisessakin elämässä ajatella muusikoiden laulavan ja soittavan. ${ }^{6}$

Kesä-elokuvassa on yhteensä 23 diegeettiseksi luokiteltavaa musiikkiesitystä. Näitä lähemmin tarkasteltaessa elokuvan merkityksen kannalta olennaisiksi muodostuvat kaksi keskeistä muuttujaa: musiikin äänilähde ja musiikin vastaanottajat. Toisin sanoen, onko kyseessä elävä vai nauhoitettu musiikki ja onko kyseessä yksityinen vai julkinen musiikinkuunteluhetki.

Autenttisentuntuisina konserttiesityksinä nähdään elokuvassa vain neljä Zooparkin ja Kinon kappaletta, jotka nähdään ja kuullaan käytännössä kokonaisina esityksinä. Koko elokuvan avaa jo mainittu Zooparkin "Drjan"-esitys,
6 Musiikin diegeettisyyden ja realistisen representaation yhteyksistä, ks. Österberg 2018, 39-40. 
joka alkaa kuvauksella tytöistä livahtamassa sisään rock-klubille (0:00:000:04:55). Samalla esitellään rock-klubin säännöt: vartijat kiertävät vahtimassa, että kukaan yleisöstä ei heilu tuolillaan eikä osoita massahysterian merkkejä. Hillitty ja asiallinen tunnelma saa voimakkaan kontrastin raflaavasta tekstistä. Tälle esitykselle kontrastoituu myös toinen, myöhempi Zooparkin lavaesiintyminen: "Zvezda rok'n'rolla", joka on ainoa konserttiesitys, joka rikkoo realismin rajat ja astuu fantastiselle, musikaaleista tutulle supradiegesiksen tasolle: fantasiaelementin mukaan tulo kuvataan väriotoksin ja split screen -teknikkaa käyttäen (01:01:15-01:04:15). Kohtauksen voi tulkita Naumenkon tai jonkun muun henkilöhahmon pään sisällä tapahtuvaksi fantasiaksi - ehkä jopa kollektiiviseksi unelmaksi siitä, mistä rockissa pitäisi olla kyse.

Kinon lavaesiintymiset sujuvat elokuvassa rauhallisemmissa merkeissä. Tämä uusi tulokas hassuine asuineen ja ultranaivistisine lyriikoineen muodostaa jyrkän kontrastin etabloituneen ja perinteisemmin rock-henkisen Zooparkin kanssa ja saa vastaan mykistyneen yleisön. "Kogda-to ty byl bitnikom" ["Joskus ennen olit beatnikki"]-laulun esitys rekonstruoi kokoonpanon legendaarisen tosielämän ensiesiintymisen Garin i giberboloidy -nimisenä ["Garin ja hyperboloidit"] Leningradin rock-klubilla syksyllä 1981 (1:04:58-1:08:09). Elokuvan narratiivin päättää puolestaan epilogina toimiva Kinon lavaesitys "Ja posadil derevo" (1:55:23-1:57:45). Näiden kahden esiintymisen väliin ajoittuu Kinon synty: heiveröinen alku ja sitten suuren yhtyeen saama haltioitunut vastaanotto lopussa. Myös se, että Zoopark aloittaa ja Kino lopettaa elokuvan viestittää, kuinka neuvostorockin valta siirtyi uudelle sukupolvelle -ja samalla kaikki ympärillä muuttui lopullisesti ja peruuttamattomasti.

Julkisten esiintymisten lisäksi elokuvan rock-muusikot esittävät tuotantoaan ystävien kesken, epävirallisissa kotikonserteissa tai muuten vaan yhdessä ollessaan. ${ }^{7}$ Majk soittaa kappaleen "Leto" rannalla (0:08:10-0:09:55), ja pian paikalle saapuu Viktor, joka ikään kuin koe-esiintymisenä soittaa kappaleensa "Bezdelnik" ["Tyhjäntoimittaja"] ja Moi druzja ["Minun ystäväni"] (0:14:400:19:33). Myöhemmin Viktor soittaa Majkin ja Nataljan keittiössä otteen juuri valmistuneesta kappaleestaan "Vosmiklassnitsa" ["Kahdeksasluokkalainen tyttö"] (0:31:50-0:33:18). Kohtaukset esittelevät paitsi muusikoiden arkea ja taiteellista kanssakäymistä, myös yleisemmän venäläisen tavan soitella kitaraa aina kun ystävät kokoontuvat yhteen. Astetta virallisempi, mutta kuitenkin

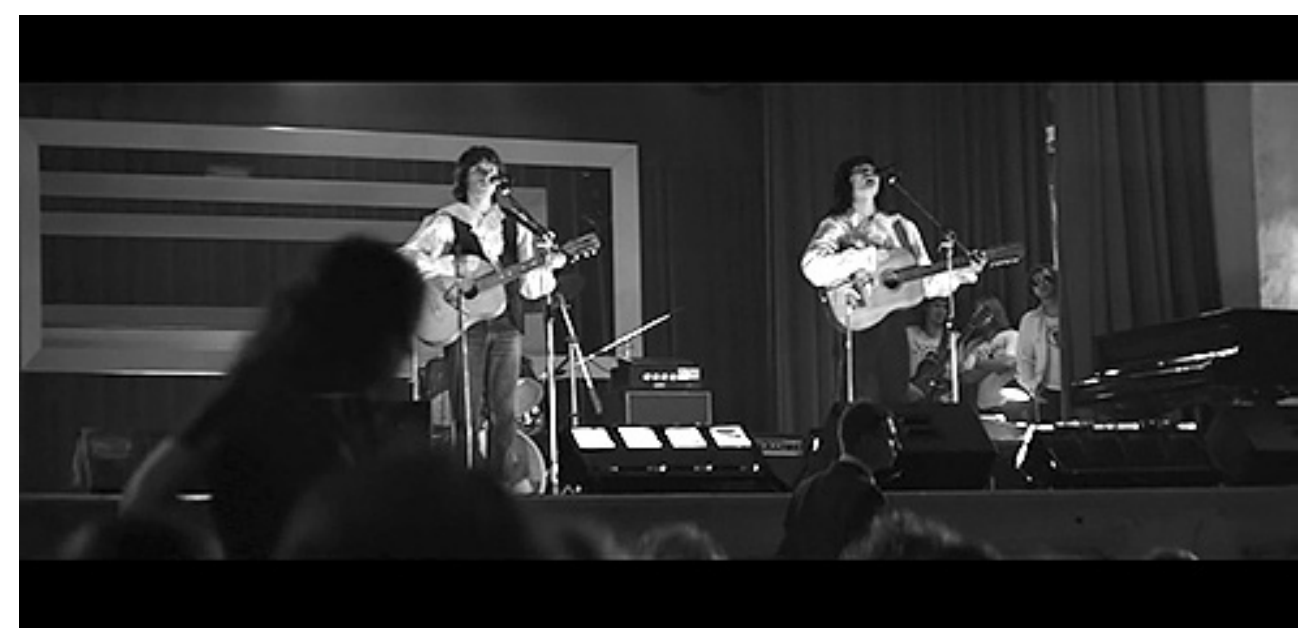

Rekonstruktio Garin ja hyberboloidit -yhtyeen ensiesiintymisestä Leningradin rockklubilla. Kuva: Kaappaus DVD:Itä.
7 Polly McMichaelin mukaan tämä yksityinen alue - sisäpihat, kodit, asunnot ja kotikonsertit - on olennainen osa Neuvostoliiton undergroundrockin identiteetin muodostusta $(2015,186)$. 
epävirallinen ja tavallaan yksityinen esitysmuoto on underground-artistien kotikonsertti eli kvartirnik. Tällaisia sisältyy elokuvaan yksi, jossa Kino esittää tilaisuuden luonnetta hauskasti reflektoivan kappaleen "Na kuhne" ["Keittiössä"] (1:28:51-1:30:57).

Varsinaisten esiintymisten - julkisten ja yksityisten - ohella muusikoiden arkeen kuuluu treenaus- ja äänityssessiot. Zoopark ja Kino näytetään ristileikkauksin treenaamassa omia kappaleitaan, ja kummallakin on omanlaisensa vaikeudet niihin liittyen (0:27:35-0:30:50). Kinon vaikeudet liittyvät siihen, etteivät bänditoverit tunnu ymmärtävän ja antavan arvoa Tsoin kappaleiden minimalismille. Zooparkia vaivaa puolestaan identiteettikriisi liittyen kappaleiden ei-venäläiseen ilmaisuun: mitä annettavaa on musiikilla, joka on vain läntisten esikuvien imitaatiota. Se, miten kappaleista puhutaan ja niitä kommentoidaan elokuvan tarinan sisällä, on tärkeä osa sen musiikkimaisemaa, vaikka liittyykin jo enemmän siihen, millä eri tavoin musiikki voi olla läsnä elokuvassa teemana, ei pelkkänä musiikkina.

Kino on ainoa yhtye, jota näytetään äänittämässä kappalettaan studio-olosuhteissa (1:24.10-1:28:51). Kyseessä on yksi yhtyeen kuuluisimmista hiteistä, "Vremja jest, a deneg net" ["Aikaa on, rahaa ei"]. Uusintaotot, Tsoin turhautuminen työn laatuun ja muiden artistien vapaa ja luova ideointi kappaleen suhteen antavat vaikutelman siitä, että katsojat saavat seurata ikonisen kappaleen hioutumista lopulliseen, tunnettuun muotoonsa. On mielenkiintoista, että tämäntyyppinen työstäminen kuvataan vain suhteessa Tsoin kappaleisiin. Naumenkon tekstit ja laulut esittäytyvät valmiina ja kiteytyneinä.

Kappaleiden tallentaminen äänitteiksi liittyy vahvasti toiseen tapaan, jolla musiikki voidaan esittää tulevan elokuvan tarinamaailman sisältä: päähenkilöt eivät itse esitä tai tee, vaan kuuntelevat musiikkia. Ja tästä on myös mitä enimmässä määrin Kesä-elokuvassa kyse. Henkilöhahmot kuulevat ja kuuntelevat nauhoitettua musiikkia sekä levysoittimilla että nauhureilla, sekä kotioloissa että julkisilla paikoilla.

Julkisten paikkojen musiikkimaisema on lähes poikkeuksetta estradaa eli Neuvostoliiton virallisesti hyväksyttyä populaari- ja viihdemusiikkia. Estrada ja muu viihdemusiikki on vain tuskin kuuluvia pätkiä julkisissa tiloissa puoluekokouksen televisiolähetys (0:53:50) tai musiikkia ruokalan radiosta (0:46:36-0:50:34), eikä näitä artisteja koskaan nähdä eikä heistä puhuta millään tasolla. Tämä on korostetusti muiden henkilöiden, massojen musiikkia, ja nimenomaan julkisten, yhteisten tilojen musiikkia. Erityisen humoristisen kontrastin luo ruokalakohtaus, jossa Kinon pojat yrittävät saada settinsä mukaan rock-klubin ohjelmistoon ja kuvailevat tuotantoaan portinvartijana toimivalle naisjohtajalle (0:46:36-0:50:34). Ruokalan radiosta kaikuvat estradakappaleet taustoittavat humoristisesti keskustelua (" ̈̈lä lupaile", "Usko minua"). Samalla on osuvaa, että nämä käytännössä elokuvan ainoat naisten laulamat kappaleet säestävät naispuolisen johtajan päätöstä Kinon kohtalosta.

Silloin kun ei kokoonnuta yhteen soittelemaan, henkilöhahmojen yksityistä tilaa määrittää vain ja ainoastaan ulkomainen rock. Natalija ja Majk kuuntelevat kahteen eri otteeseen levyjä kotonaan, heidän soittolistallaan on Velvet Undergroundin "Waiting for the Man" (0:34:04-0:34:54) ja T-Rexin "20th Century Boy" (1:00:22-1:00:33). Kun Majk menee kyläilemään rock-legenda Boris Grebenštšikovin (elokuvassa nimellä "Bob") luo, tämän kotona soi David Bowien "Ashes to Ashes" (1:16:49-1:17:32).

Yhden välähdyksen muiden kuin rock-porukan yksityiseen musiikinkuunteluun tarjoaa elokuvan alkupuolen kohtaus rannalla, jossa Viktor ja kitaristi Leonid törmäävät rannalla retkeilevään vanhempaan seurueeseen, 
joiden autoradiosta kaikuu bardi Arkadi Severnyin "Pokazanija nevinovnogo" ["Syyttömän puolustus"] (0:07:40). Näin bardimusiikki ja rock rinnastuvat yksityisen musiikkimaun edustajina, ja kontrastoituvat yhdessä estradaan, joka täyttää julkiset tilat. Toisaalta rockin ja bardimuusikon eron voi ajatella määrittyvän sukupolvikysymyksen kautta: rock-musiikki on vallannut nuorten arjessa sen tilan, jonka vanhempi sukupolvi on varannut bardeille. Elokuvan representaatio tukee näin sitä, millaisena underground-rokkarit venäläisessä rock-mytologiassa perinteisesti on haluttu nähdä: bardiperinteen jatkajina (Troitski 1991, 45).

Mielenkiintoisena näyttäytyy se seikka, että venäläistä rockia ei äänitteiden avulla juurikaan elokuvassa kuunnella. Ainoa kerta on kohtaus, jossa Majk tuo Bobille kuunneltavaksi Kinon demon kappaleesta "Moe nastroenie" (1:20:39). Tämän voi ajatella indikoivan jonkinlaista muutosta, joka on koittamassa neuvostorock-kulttuuriin: Kinon ja uuden rokkarisukupolven myötä tapahtuu myös siirtymä elävästä musiikista objektiorientoituneempaan musiikinkulutukseen. Samalla tämä kappale ja tämä hetki on ainoa koko elokuvassa, jolloin diegeettinen laulu nousee tai siirtyy ei-diegeettiselle tasolle. Majk ja Bob siirtyvät keittiöstä rakennuksen katolle visioimaan ja unelmoimaan, samalla kappaleen volyymi nousee ja diegeettiset äänet katoavat. Tämä on yleisesti käytetty keino elokuvamusiikissa, johon sisältyy hienovarainen vihje kerronnan noususta astetta eeppisemmälle tasolle (Österberg 2018, 40).

Musiikin läsnäolo diegesiksessä tapahtuu monella muullakin tavalla kuin vain auditiivisena kokemuksena. Toisin sanoen, diegeettinen musiikki on melkein aina elokuvassa jotain muutakin kuin musiikkia: se on läsnä esineinä (esim. soittimet, äänentoistolaitteet, tallenteet), henkilöhahmoina (muusikot, mutta myös muut musiikintekemiseen liittyvät toimijat, esim. tuottaja), paikkoina (esim. konserttisalit) ja toimintoina (esim. tanssiminen, aktiivinen kuuntelu). Suurin osa näistä voivat viitata musiikkiin elokuvallisena teemana silloinkin, kun musiikkia ei kuulla lainkaan (ks. Österberg 2018, 145-148).

Musiikinkuuntelulaitteiden lisäksi elokuvassa saavat paljon huomiota myös muut musiikkikulttuuriin liittyvät visuaaliset elementit: levyjen kannet, artistien kuvat ja julisteet, sekä laulujen sanat kirjoitettuna tekstinä. Keskeisessä roolissa on erityisesti Majkin ja Viktorin harrastama kopiointi: molemmat piirtävät mallista levynkansia sekä artistien muotokuvia (esim. Marc Bolan,

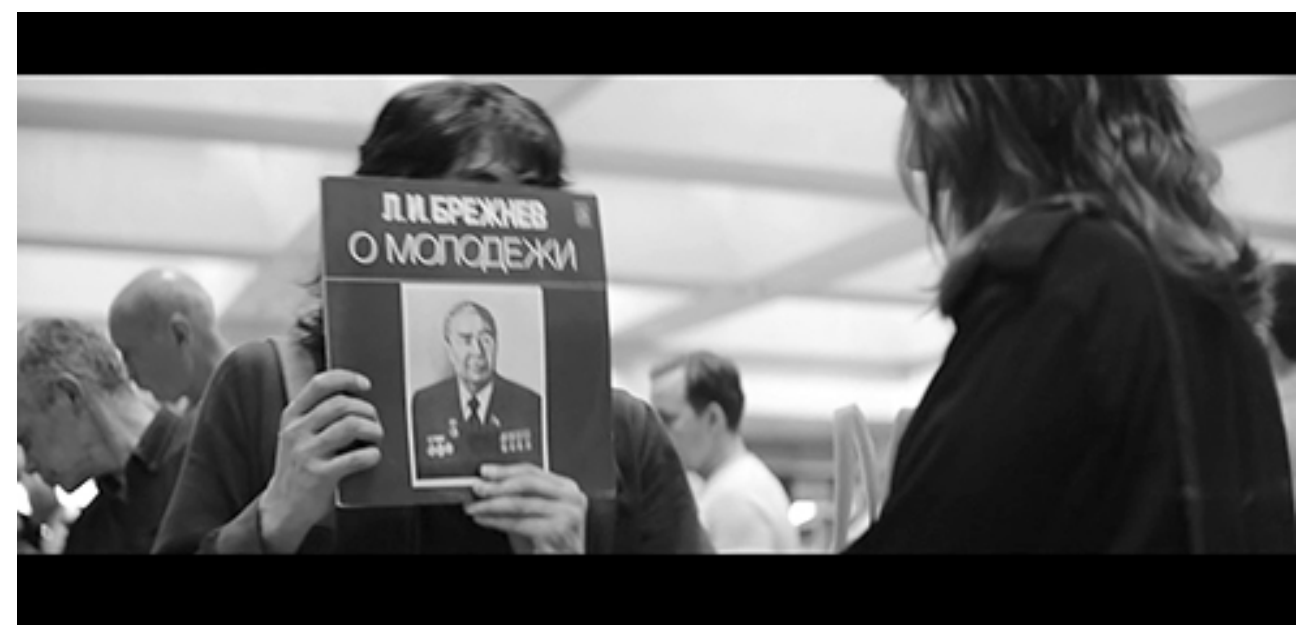

Neuvostoliiton omaa levynkansitaidetta - Leonid Brežnev: Nuorisosta. Kuva: Kaappaus DVD:Itä. 
The Beatles). Majk lisäksi kopioi muistikirjoihinsa englanninkielisten laulujen sanoja sekä kääntää näitä venäjäksi. Nämä artefaktit ja toiminnot eivät liity niinkään muusikkouden vaan ensisijaisesti fanikulttuurin kuvaukseen. On myös huomattava, että kyseessä on elokuvan kontekstissa aina ainoastaan ulkomaisiin, läntisiin artisteihin liittyvistä artefakteista ja heihin kohdistuvasta fanittamisesta. Ainoa neuvostoliittolainen levynkansi, joka elokuvassa vilahtaa on tallenne Leonid Brezhnevin puheesta O molodjoži ["Nuorisosta"].

Myös dialogissa ulkomaiset rokkarit ja bändit saavat paljon sijaa. Rumpukoneen tuonti Kinon armeijaan värvätyn rumpalin tilalle saa yhtyeen jäsenet pohtimaan, että heidän soundinsa muuttuu diskoksi, olisipa edes niin kuin Duran Duranilla - tosin "David Bowiekin soittaa diskoa". Majkin ja Nataljian suhteessa ulkomaiset artistit näyttelevät suurta roolia: alunperin he ovat tavanneet juuri David Bowien kuuntelun merkeissä ja illalla kotona he sängyssä pohtivat kumpaa kuunnellaan - T-Rexiä vai Lou Reedia. Kun Nataljia vastaa, että ihan sama, se on merkki suhteen kriisistä. Myös Majkin omalle identiteetille suhde ulkomaisiin artisteihin on olennainen: "Heillä on Stones, Doors, Led Zeppelin, Clash, Joy Division, Bowie, Dylan, T-Rex, jopa Blondie - mihin minua siellä tarvitaan?"

Mielenkiintoista on, että kuvien ja puheen tasolla Blondie-yhtye on läsnä toistuvasti, mikä tuo naisetkin ainakin osittain mukaan ihailtuun musiikilliseen repertoaariin, elokuvassa nimeltä mainitsemattoman laulusolisti Deborah Harryn muodossa. Tosin heidän musiikistaan puhuttaessa korostuukin laulujen sanoitusten tyhjänpäiväisyys - ja naisen kevytkenkäisyys. Natalja pyytää Majkia kertomaan, mistä Blondien levyllä lauletaan, jolloin Majk tiivistää: "No, että soita minulle, milloin haluat, vaikka keskellä yötä."

Elokuvan musiikin sijoittelu, esittely ja käsittely diegesiksen tasolla kertoo eri musiikkityylien hierarkiasta ja rooleista elokuvan kuvaamassa maailmassa sekä sen yhteiskunnallisella että yksityisellä tasolla. Tietyt musiikkityylit kuuluvat julkiseen ja tietyt yksityiseen tilaan. Musiikin kuluttamiseen liittyvät artefaktit ja nauhoitteet liittyvät lähestulkoon yksinomaan läntiseen musiikkiin. Venäläinen rock puolestaan on elävää musiikkia ja yhdessäoloa. Tämä jaottelu on yhdenmukainen myös neuvostoajan diegeettisen rockin käyttöön liittyvien tendenssien kanssa (Österberg 2018, 111-112). Musiikkiteeman käsittely diegesiksen eri elementtien kautta paljastaa myös sen, että Kesä ei ole vain elokuva muusikkona olemisesta, vaan myös elokuva musiikkiin liittyvästä fanikulttuurista. Keskiössä ei ole myöskään neuvostorockin suhde muuhun aikalaisneuvostomusiikkiin, vaan ennen kaikkea neuvostorockin ja -rokkareiden suhde läntiseen rockiin.

\section{Laulut ja musiikki diegesiksen ulkopuolella}

Kesä-elokuvan musiikkia ja lauluja kuullaan myös diegesiksen ulkopuolisina elementteinä. Perinteisen ei-diegeettisen instrumentaalisen, alkuperäisen ja taustalla kuultavan musiikkiaineksen lisäksi elokuvassa on paljon lauluja, joiden suhde diegesikseen on huomattavasti monimutkaisempi ja moniulotteisempi. Diegeettisen ja ei-diegeettisen musiikin lisäksi käsittelyä voidaan laajentaa ottamalla käyttöön Guido Heldtin (2013, 23-27) ekstrafiktiivisyys sekä Altmanin (1987, 62-85) ja Heldtin (2013, 106-107, 137-138) käsittelemä supradiegeettisyys.

Kesässä kuultava alkuperäismusiikki on Zveri-yhtyeen German Osipovin improvisoimaa kitarointia. Se kuullaan aina puhtaasti ei-diegeettisenä. Tätä 
haikean viipyilevää ja nostalgista tunnelmaa luovaa kitaraimprovisaatiota kuullaan elokuvassa yhteensä kahdeksan kertaa ja peräti puolet toistoista kuullaan elokuvan alkupuolen yli kymmenminuuttisen rantajakson aikana (0:08:10-0:20:39). Jakson aikana tämä musiikki ikään kuin merkitsee kolme elokuvan kannalta keskeistä teemaa.

Ensimmäinen on Majkin, Nataljan ja Viktorin välinen kolmiodraama: kitaramusiikkia kuullaan, kun Natalja juttelee Viktorin kanssa kahdestaan ensimmäisen kerran (0:13:30-0:14:25), sekä sen jälkeen kun hän palaa Majkin kainaloon ja he juttelevat yhdessä Viktorista (0:19:33-0:20:39). Musiikki toistuu, kun Majk palaa vuoteeseen Nataljan viereen tämän vietettyä (oletetusti) yön Viktorin kanssa (1:23:08-1:24:04). Huomionarvoista on myös se, että kun Vitja ja Natalja juttelevat viimeisen kerran ja päättävät olla jatkamatta "suhdetta" sen pidemmälle, taustalla ei kuulla musiikkia lainkaan (1:37:45). Taika on ohi.

Toinen ei-diegeettisen alkuperäismusiikin merkitsemä teema on elokuvan itsereflektio: yksi henkilöhahmoista on dokumenttifilmin kuvaaja, joka seuraa rokkareita sivusta ja kuvaa heidän arkeaan. ${ }^{8}$ Instrumentaalimusiikki kuullaan toistuvasti hetkinä, jolloin myös dokumentaristi näkyy kuvassa kameransa kanssa, ja tällöin myös hänen kameransa surina kuuluu ei-diegeettisen taustamusiikin läpi: hetken ajan voimakkaampana ja sitten se taas häipyy (0:10:42-0:11:06; 0:14:30-0:15:36; 1:08:09-1:10:30). Nämä itsereflektiiviset hetket korostavat ei-diegeettisen musiikin konventionaalista, ehdollista luonnetta; sitä että se on klassisen venäläisen elokuvamusiikin teorian mukaisesti "musiikkia elokuvan tekijältä" ["Muzyka ot avtora"] (Korganov \& Frolov 1964, 120-125).

Kolmas teema on ranta ja kesä - musiikkia kuullaan, kun seuraamme muusikkojen iloista kisailua ja juoksentelua jo pimenevällä rannalla. Tähän teemaan palataan elokuvan loppupuolen kohtauksessa, jossa Punkkari siirtyy ikuisesti osaksi tuota idyllistä rantamaisemaa (1:45:04-1:45:48). Mystisellä tavalla hän siirtyy elokuvaan elokuvassa: astuu seinälle heijastetun filmin tuolle puolen ja hitaasti katoaa aaltoihin Osipovin kitaran säestämänä.

Ekstrafiktiivisyys - tai fiktion ulkopuolisuus - on käsite, jota Guido Heldt (2013, 23-27) käyttää kuvaamaan alku- ja lopputekstijaksojen suhdetta elokuvan varsinaiseen rakenteeseen. Kesä-elokuvassa on kuitenkin myös tarinan lomassa kohtauksia, joita voi perustellusti tarkastella ekstrafiktiivisinä insert-

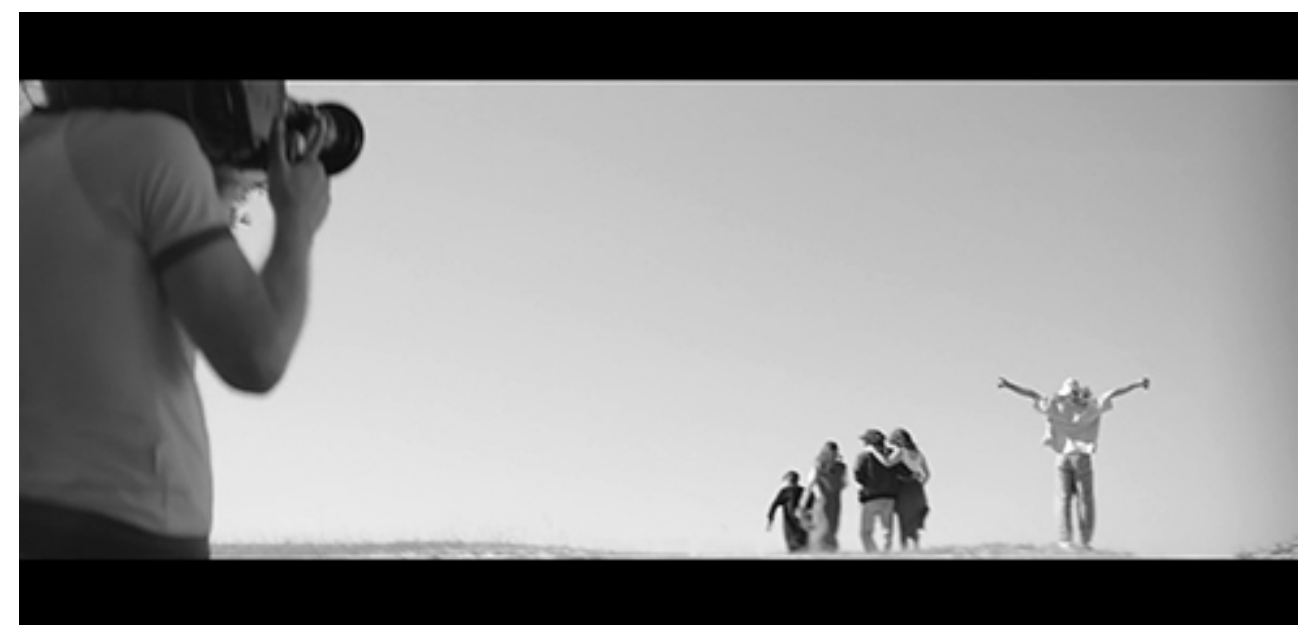

Musiikkia tekijältä - Kesän tähdet ja elokuvaaja (Jevgeni Grigorjev) elokuvassa. Kuva: Kaappaus DVD:Itä.
8 Dokumentaristia esittää tosielämän dokumentintekijä, ohjaaja Jevgeni Grigorjev, jonka tuorein dokumentti Pro Rok ("Rockista", 2017) pyrkii määrittämään tämän hetken Venäjän rock-tähtien uuden sukupolven, mutta löytääkin vain "määrätietoisuuden ja energian puutetta" (Ryabchikova 2018). 


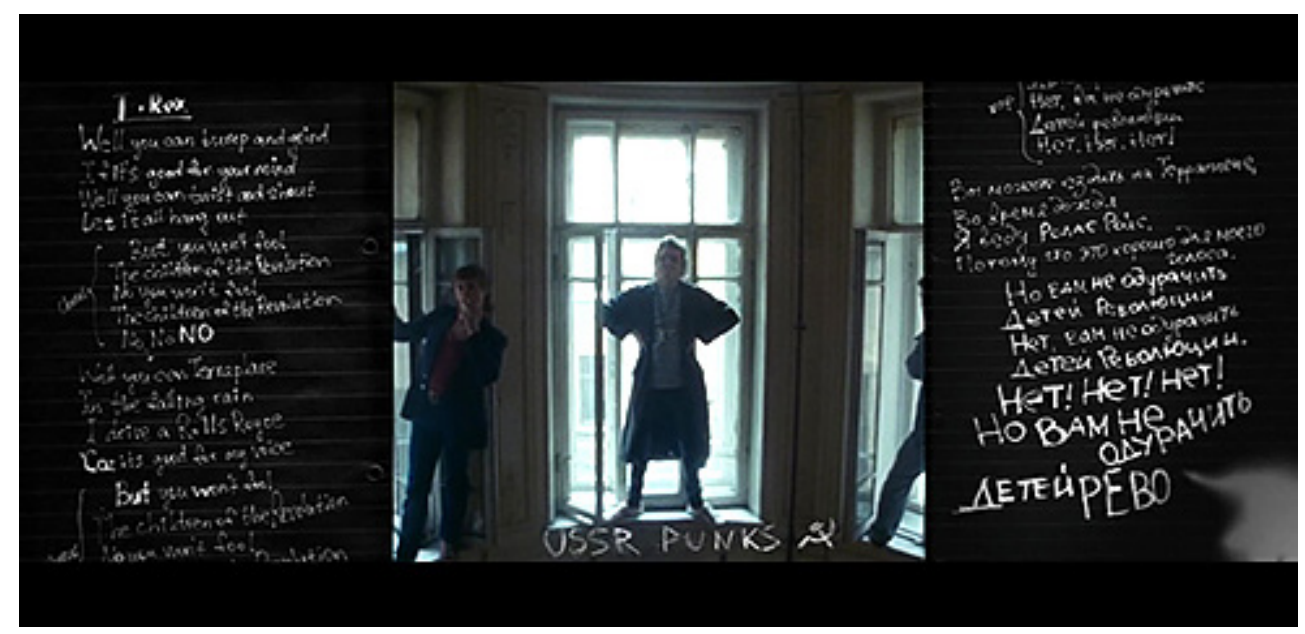

Vallankumouksen lapset: elokuvan keskikohdan merkitsevä ekstrafiktiivinen insertti. Kuva: Kaappaus DVD:Itä.

teinä. Tällaisia inserttejä on elokuvassa kaikkiaan kolme. Niillä on sangen tarkka sijainti elokuvan kerronnallisessa rakenteessa: ensimmäinen erottaa prologin ja varsinaisen tarinan (0:06:40-0:07:20), toinen sijoittuu varsinaisen tarinaosan keskikohtaan (0:52:03-0:52:25) ja kolmas insertti erottaa tarinan lopun ja epilogin toisistaan (1:52:06-1:52:50).

Näiden inserttien kuvamateriaali poikkeaa muusta elokuvassa esitetystä monella tapaa: se on värillistä ja siitä puuttuu diegeettinen ääni. Näissä katkelmissa elokuvan henkilöhahmot ovat lisäksi vuorovaikutuksessa kameran kanssa: poseeraavat ja pelleilevät sille, ja hahmojen liikkeet toistuvat hieman nopeutettuna, samalla kun kuulemme projektorin rahinaa. On mahdollista tulkita, että kyseessä on elokuvan fiktiivisen dokumentaristin kuvaamaa aineistoa. Inserttien sisältämä filmimateriaali olisi siis itsessään perusteltua käsitellä elokuvana elokuvassa (diegeettisenä elementtinä), mutta läsnä on lisäksi muita elementtejä, jotka korostavat inserttien ekstratekstuaalisuutta: kuvamateriaali on kehystetty paksulla mustalla kehyksellä, jonka päälle ilmestyy animoituja piirroksia ja tekstiä, ja kameran rahinan lisäksi näiden kohtausten aikana kuullaan jokin, yleensä diegesiksen ulkopuolelta kumpuava laulu.

Laulut, jotka inserteissä kuullaan, ovat T-Rexin "Broken Hearted Blues" ja "Children of the Revolution" sekä Majk Naumenkon "6 utra". T-Rexin kappaleiden aikana kuvassa näkyy vasemmalla puolella kappaleen alkuperäiset, englanninkieliset sanat käsin kirjoitettuna ja laulun edetessä oikealle puolelle kirjoittuvat samat sanat venäjäksi käännettynä. Nämä ovat lopputekstien mukaan Naumenkon autenttisten muistikirjojen merkintöjen animointeja. Näin laulut saavat uuden tekstuaalisen substanssin: lyriikat muodostavat elokuvaan oman visuaalisen tekstuurinsa. Kahdella ensimmäisellä kerralla laulut ovat ulkomaisia ja huomio on tekstien kääntämisessä englannista venäjäksi, mutta kolmannella ja viimeisellä kerralla kuullaan autenttinen venäjänkielinen rock-kappale ja kuvaan kirjoittuva teksti on vain venäjää. Siirtymä läntisten mallien imitaatiosta autenttiseen, omaperäiseen kansalliseen ilmaisuun saa konkreettisen visuaalisen ilmauksensa.

Kesän ekstrafiktiiviset insertit tuovat hallittua etäisyyttä ja luovat rakennetta tarinaan, mutta niiden vastapainona toimivat elokuvaan sijoitetut supradiegeettiset esitykset, jotka puolestaan edustavat puhdasta kaaosta ja anarkiaa. 


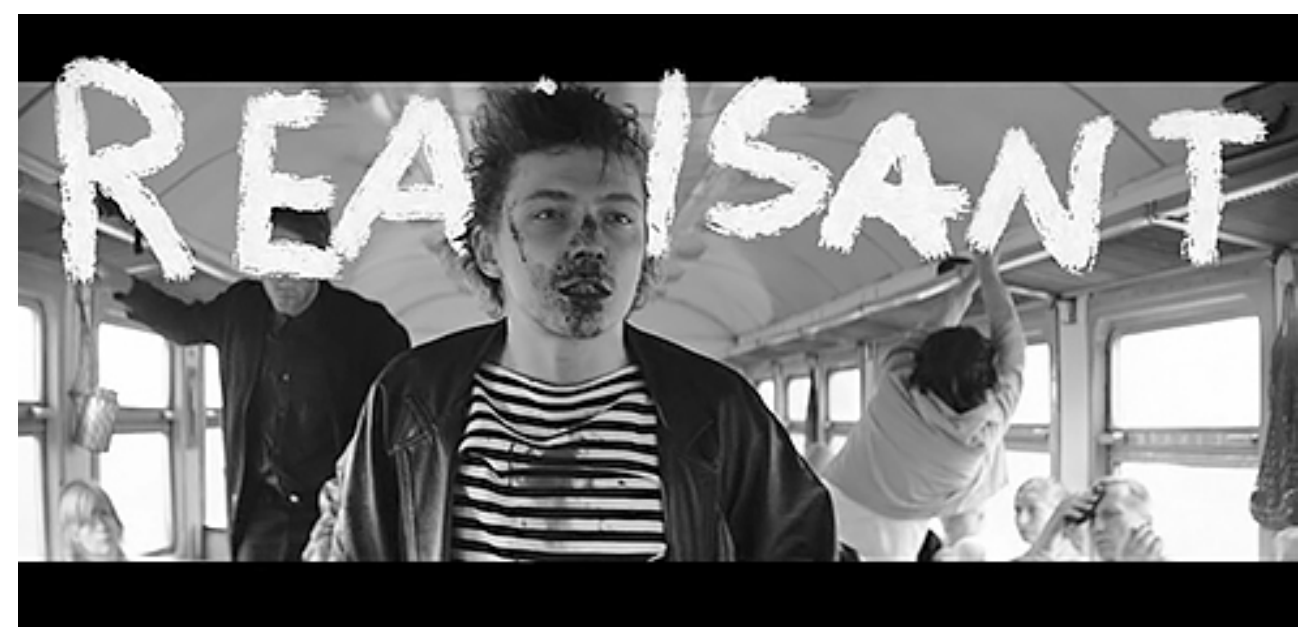

"Réalisant mon espoir..." - Punkkari (Aleksandr Gortšilin) toteuttaa haaveensa "Psycho killer"-musikaalinumerossa. Kuva: Kaappaus DVD:Itä.

Supradiegeettinen on Altmanin (1987, 62-85) ja Heldtin (2013, 106-107, 137-138) määritelmän mukaan taso, jolla elokuvamusikaalien musiikkinumerot voidaan katsoa suhteutuvan diegesikseen. Käytännössä se siis tarkoittaa elokuvamusikaalien tapaa integroida ei-realistiseen representaation pohjautuvia laulu- ja tanssinumeroita kerrontaan. Siirtymävaiheessa diegesiksestä supradiegeettiselle tasolla tapahtuu yleensä äänihälventymä (audio dissolve), jossa muutos äänen laadussa ja äänen lähteiden realistisuudessa merkitsee myös siirtymää realistisesta representaatiosta fantasian tasolle.

Kesä-elokuvassa on perinteisesti määriteltäviä musikaaliesityksiä yhteensä kolme kappaletta: "Psycho Killer", "Passenger" ja "Perfect Day". Kaksi ensin mainittua tapahtuvat julkisessa liikennevälineessä: päähenkilöt matkustavat lähijunassa ja trollikassa ja matkustajat yhtyvät lauluun. "Psycho Killer" toimii punkkarin ja sukupolvensa rokkareiden tunnustuksena, luonteenkuvauksena ja energianpurkauksena, jossa muut matkustajat kommentoivat laulua ja tanssia laulun sanoihin yhtyen (0:22:10-0:25:06). "Passenger"-kappale puolestaan tulkitaan trollikkabussissa, ja muut matkustajat esittävät sen Viktorille ja Nataljalle, jotka yrittävät luovia tiensä tungoksen läpi ja päättävät lopulta jäädä kyydistä (0:40:55-0:44:03). "Perfect Day" puolestaan sanoittaa Majkin tuntemuksia tilanteessa, jossa hän kuljeksii sateisilla kaduilla Nataljan ja Viktorin lavastetun kohtaamisen aikana (1:13:53-1:16:15). Mielenkiintoista on, että elokuvan kuvaamat laulajat - Tsoi tai Majk - eivät kumpikaan laula mitään näissä musikaalinumeroissa. Laulamisen hoitavat pääasiassa sivulliset, elokuvan statistit, tavalliset neuvostokansalaiset. "Perfect Dayn" tapauksessa lauluosuudet hoitavat kohtauksen naishahmot, jotka laulavat laulunsa ikään kuin kommentoiden Majkin mietteitä ja tilannetta.

Olennainen osa näiden kohtauksen kehystämistä on erityisesti siihen rooliin kirjoitettu ja tavallaan ekstradiegeettinen hahmo itsekin, nimeltä Skeptikko. Siten musikaalinumerot eivät ala pelkästään siirtymällä diegeettisestä eidiegeettiseen musiikkiin eivätkä pääty käänteiseen siirtymään, vaan numerot aloittaa ja/tai lopettaa Skeptikon kommentit: "Nyt kuullaan se ja se laulu, siltä ja siltä esittäjältä." Esittäjien nimiksi hän listaa aina laulujen alkuperäiset esittäjät: "Puhuvat päät" ["Govorjaštšije golovy" = Talking Heads], Iggy Pop, Lou Reed - siitäkin huolimatta, että fiktion sisällä laulujen esittäjinä 
toimii pääsääntöisesti Neuvostoliiton "rivikansalaiset". Skeptikko kääntää laulun sanoja venäjäksi elokuvayleisölle sekä toteaa muutamaan otteeseen laulunumeron päätyttyä: "Tätä ei todellisuudessa tapahtunut." Aivan kuin musikaalinumero ei kykenisi ilmaisemaan omaa fantastista luonnettaan muilla elokuvallisilla keinoilla: konventio dekonstruoituu.

Elokuvan kliimaksina toimii jakso, jossa kaksi laulua rikkoo siihen asti totutun laulujen ja musiikin rakenteellisen distribuution kaavan. Näyttelijä Gortšilinin esittämä "Vstselo" (1:34:40-1:37:45) ja Shortparis-yhtyeen versio laulusta "All the Young Dudes" (1:39:40-1:43:10) tapahtuvat ikään kuin autenttisina esityksinä tarinamaailmassa, mutta eivät ole määriteltävissä diegeettisiksi konserttiesityksiksi eivätkä supradiegeettisiksi musikaalinumeroiksikaan. Rajat murtuvat, kun nämä kaksi kappaletta vyöryvät realistisen kotikonserttikohtauksen jatkeeksi ja rikkovat diegesiksen rajat ja sisältävät elementtejä oikeastaan kaikista tähän asti listatuista musiikin eri tavoista suhteutua diegesikseen.

Punkkari-henkilöhahmon esittämää "Vsetselo"-laulua ei voi laskea realistiseksi diegeettiseksi esitykseksi, vaikka sen esittääkin muusikko samassa paikassa ja samalle yleisölle kuin Kinokin on esiintynyt hetkeä aiemmin. Tämä johtuu siitä, että kappaleen musiikki ei tule mistään realistisesta lähteestä. Kyseessä on musikaalinumero, mutta se eroaa olennaisesti elokuvan muista musikaalinumeroista siinä, että sen aikana ei esiinny mitään ei-diegeettisiä visuaalisia elementtejä - eli animointeja ja grafiikoita, eikä esitys myöskään saa minkäänlaista johdantoa tai kommentaareja Skeptikolta.

Lähestulkoon heti tämän esityksen perään aloittaa Shortparis-yhtye esityksensä samaisessa olohuoneessa. Heillä on mukanaan kaikki musiikintuottamiseen tarvittavat elementit: mikrofoni, rummut, kitarat. Tässäkään kohtauksessa ei kuitenkaan ole kyse realistisesta esityksestä: esiintyjänä on 2010-luvun yhtye, joka ei esitä elokuvan kontekstissa olevansa mikään toinen yhtye, ja jonka sijoittaminen sellaisenaan 1980-luvun alun neuvostoliittolaisen kotikonsertin olohuoneeseen on melkoinen anakronismi. Keskellä näennäisen realistista mutta kuitenkin fiktiivistä neuvostoarjen kuvausta autenttinen yhtye näyttäytyykin epärealistisena elementtinä.

Kappaleen supradiegeettisyyttä korostaa se, että sen johdattelee katsojille Skeptikko-hahmo: "Nyt kuulemme laulun Mott the Hooplelta 'All the Young Dudes'." Konserttiesityksen lomaan on editoitu aikaisempia ekstradiegeettisiä inserttejä muistuttavaa kuvamateriaalia, jossa elokuvan henkilöhahmot asettuvat eläviksi asetelmiksi ja rekonstruoivat yhteensä kolmentoista läntisen rock- ja pop-levyn kannet. ${ }^{9}$ Laulussa lauletaan "Rolling Stones, Beatles, T. Rex - kaikki nuoret itsetuhoiset miehet tietävät jo sen - maailmanloppu tulee", samalla olohuoneen valaistus muuttuu todellista rokkikonserttia muistuttavaksi ja yleisö heittäytyy ekstaattiseen orgiaan. Läntiset ja venäläiset elementit, neuvostomenneisyys ja venäjän nykyhetki, niin fiktiivisinä kuin todellisinakin sekoittuvat ja sulavat yhteen.

Kliimaksinomaisen orgiakohtauksen jälkeen elokuvan varsinainen tarinaosa päättyy raukeaan seesteisyyteen. Huolimatta siitä, että humoristinen "Leto" on lainannut elokuvalle nimensä, temaattiseksi avaintekstiksi nousee itse asiassa aivan toinen Naumenkon kappale - "6 utra". Viimeinen kohtaus ennen epilogia näyttää takaumana Majkin paluun vaimonsa viereen tämän oletettavasti vietettyä yönsä Tsoin kanssa, ja kohtausta säestää elokuvan ensimmäinen ja ainoa, täysin puhtaasti ei-diegeettiseltä tasolta kuultava rocklaulu (1:48:35-1:52:06). Laulun sanoissa rock-tähti herää aamulla rauhaisiin mietteisiin, kun koko kaupunki on vielä hiljaa ja ikään kuin päättää: maailma
9 Rekonstruoidut kansikuvat ovat järjestyksessä: Billy Joel: The Stranger (1977); The Tornadoes: Bustin' Surfboards (1963); T. Rex: The Slider (1972), The Velvet Underground: The Velvet Underground \& Nico (1967); Rolling Stones: Sticky Fingers (1971); Ike \& Tina Turner: Outta Season (1968); Blondie: Eat to the Beat (1979); The Beatles: Abbey Road (1969); John Lennon \& Yoko Ono: Double Fantasy (1980); Pink Floyd: Wish You Were Here (1975); Richard Hell and the Voidoids: Blank Generation (1977); The Beatles: Meet the Beatles (1964); The Who: My Generation (1965); Echo and the Bunnymen: Heaven Up Here (1981). 


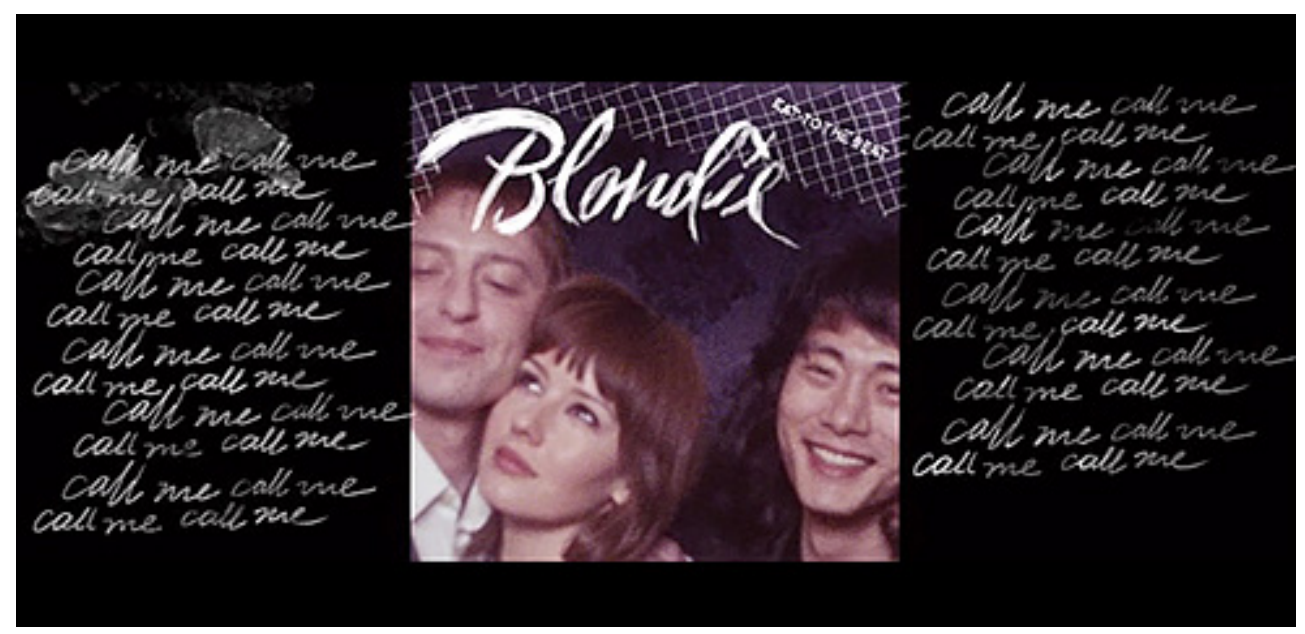

Tableau vivant vuonna 2018: Kesän näyttelijät asettuvat Blondien levyn kanneksi. Kuva: Kaappaus DVD:Itä.

on ehkä kuin eläintarha ["zoopark"], mutta rakastan kaikkia ja kaikkea siinä; elämä on ehkä pieni, mutta elämä on hyvä. Laulu tuo päähenkilöiden välille viritellyn kolmiodraaman rauhaisaan päätökseen ja ratkaisee siten elokuvan kuvaamaan rakkaustarinaan liittyvän narratiivisen konfliktin. Toisin sanoen kappale irtoaa omasta synty- ja esityskontekstistaan ja kuvaa jotain tärkeää asiaa tämän elokuvan tarinan sisällä - toimii siis "elokuvamusiikkina" perinteisessä mielessä.

\section{Lopuksi}

Kesän musiikin merkityksen luomisessa keskeinen tekijä on musiikkikatkelmien rakenteellinen distribuutio elokuvan kerronnassa. Olennaista musiikin roolille elokuvan rakenteessa ei ole pelkästään se, minkälaista musiikki on, vaan myös mitä suurimmassa määrin se, miten se kerronnan tasoihin sijoittuu ja miten se tarinan sisällä motivoidaan ja miten sitä kommentoidaan. Kesän musiikki jakautuu toisaalta jo olemassa oleviin lauluihin (joko alkuperäisinä tai uudelleentulkintoina) sekä elokuvaa varten sävellettyyn alkuperäismusiikkiin ja läsnä on oikeastaan neljä diegeettisyyden tasoa: diegeettinen, eidiegeettinen, ekstrafiktiivinen ja supradiegeettinen. Jokaisella näistä tasoista on omanlainen musiikkinsa, ja niillä on omat visuaaliset ja auditiiviset tunnuksensa myös. Kappaleissa kuullaan sangen vähän toistoa, joten elokuvan struktuuri rakentuukin juuri sen ympärille, miten tietyt musiikkilajit toistuvat tietynlaisissa positioissa suhteessa diegesikseen.

Diegeettisen musiikin runsaus ja ennen kaikkea musiikin esittämisen ja kuuntelun korostaminen toimintana diegesiksessä luo vahvan vaikutelman realistisesta representaatiosta. Nojaaminen toisaalta dokumentaarisen esittämisen tapaan, mitä korostaa elokuvan mustavalkoisuus, toisaalta neuvostoelokuvan ja perestroika-elokuvan tapaan kuvata rock-musiikkia: autenttisina konserttiesityksinä (Österberg 2018, 111-112). Tarina rockista, jonka Kesä kertoo, on loppujen lopuksi sama tarina, jonka jo 1980-luvun perestroikaaikana tehdyt rock-elokuvat ja -dokumentit ovat jo aikanaan kertoneet. Tässä tarinassa rock astuu undergroundista mainstreamiin ja autenttinen, venäläinen 
rock-ilmaisu syntyy ja sen etunenässä on Viktor Tsoi. Sitä Kesä-elokuvan nimenkin voi tulkita merkitsevän - kesä ei ole vain politiikkaa ja perestroikaa, vaan se on ennen kaikkea Kino-yhtyeen saapuminen kansalliseen kulttuuriseen tietoisuuteen.

Musiikin läsnäolo elokuvan diegesiksessä musiikin kuuntelemisen ja kuuntelun liittyvien artefaktien kautta tuo esiin myös sen, että kyseessä ei ole pelkästään elokuva muusikkoudesta vaan myös elokuva musiikin fanittamisesta ja fanikulttuurista - ja ennen kaikkea läntisen musiikin fanittamisesta. Kesän kontribuutio venäläisten rock-elokuvien kaanoniin on siten venäläisyyden ja läntisen kulttuurin suhteen tarkastelu: juuri se muodostuu erottavaksi tekijäksi elokuvan Majkin ja Viktorin artisti-identiteetille. Voimakas ripustautuminen läntisiin artisteihin on myös merkki siitä, että Majk edustaa ensimmäistä ja väistyvää vaihetta, kun taas Viktor, jolle läntiset artistit eivät toimi minkäänlaisena referenttinä, edustaa uutta aikakautta. Ajatus siitä, että siirrytään anglo-amerikkalaisen musiikin kääntämisestä ja imitoinnista johonkin kansallisempaan ilmaisuun, onkin usein keskeinen elementti kansallisen rock-myytin luomisessa.

Kesä-elokuva vahvistaa myyttiä neuvostorockin siirtymästä undergroundista mainstreamiin paitsi dokumentaaristen musiikkiesitysten myös fantastisen musikaalin keinoin. ${ }^{10}$ Se on yhtä aikaa sekä realistinen musiikkielokuva että epärealistinen musikaalielokuva. Tämä paradoksaalinen suhtautuminen elokuvan musiikkistrategiassa ehkä osittain selittää elokuvan vastaanotossa esiin nousseen - ja kieltämättä hieman epärealistisen ja kohtuuttomankin - vaatimuksen fiktioelokuvan totuudenmukaisuudelle. Mutta olennaista elokuvan musiikkistrategiassa on, että fantasiaan tukeutuvat ensisijaisesti läntiset rockkappaleet. Musikaalinumeroiksi puetut tulkinnat anglo-amerikkalaisista rockklassikoista irrottavat kyseiset kappaleet totaalisesti omasta, alkuperäisestä kontekstistaan ja niille luodaan uusi, puhtaasti elokuvan omaan, sisäiseen logiikkaan nojaava konteksti. Näin uusia elokuvallisia merkityksiä syntyy. Tässä roolijaossa kuitenkin käy niin, että neuvostoajan rock-laulut kertovat loppujen lopuksi jälleen kerran vain omasta syntykontekstistaan.

Kaikista nyansseista ja musiikin tasojen hienovaraisista siirtymistä huolimatta Kesä on kuitenkin perimmiltään juuri sitä mitä se päällisin puolin näyttää olevankin: elokuva neuvostorockista. Ja tämä auttamatta asemoi myös elokuvan sisältämän neuvostorock-musiikin siten, että se ei pysty kertomaan mistään muusta kuin itsestään. Kulttuurinen myytti laulujen ja artistien ympärillä on edelleen liian voimakas, jotta laulut voisivat irrota syntykontekstistaan. Ja tämä myytti tulee todennäköisesti lähivuosina vain vahvistumaan entisestään, sillä Kesän siivittämänä on tällä hetkellä ilmeisesti valmisteilla useampikin Viktor Tsoin elämästä ja merkityksestä kertova uusi elokuva.
10 Olennainen referentti tässä on Valeri Todorovskin Stiljagi (2008), puhdasoppinen musikaali neuvostorokkarien myyttisistä 1950-luvun kantaisistä.

\section{Elokuvat}

Assa (1987) Tuotanto: Neuvostoliitto, Mosfilm. Ohjaaja: Sergei Solovjov.

Piikki (Igla, 1988) Tuotanto: Neuvostoliitto, Kazahfilm. Ohjaaja: Rašid Nugmanov.

Kesä (Leto, 2018) Tuotanto: Venäjä, Hype Film. Ohjaaja: Kirill Serebrennikov.

Murto yössä (Vzlomštšik, 1986) Tuotanto: Neuvostoliitto, Lenfilm. Ohjaaja: Valeri Ogorodnikov.

Posle leta (2018) Tuotanto: Venäjä, Hype Productions. Ohjaaja: Kirill Serebrennikov.

Veli (Brat, 1997) Tuotanto: Venäjä, Kinokompanija STV. Ohjaus: Aleksei Balabanov. 


\section{Lähteet}

Altman, Rick (1987) The American Film Musical. Bloomington: Indiana University Press.

Beumers, Birgit (2018) Summer - L'été. Review. Splitscreen. <https://splitscreen-review. $\mathrm{fr} / 2013 / 05 / 23 /$ expositions-festivals/summer-lete/> (Tarkistettu 2.1.2019).

Cushman, Thomas (1995) Notes from Underground. Rock Music Counterculture in Russia. Albany: State University of New York Press.

Egorova, Tatiana (1997) Soviet Film Music. An Historical Survey (käännös Tatiana A. Ganf ja Natalia A. Egunova). Amsterdam: Harwood Academic Publishers.

Gorbman, Claudia (1987) Unheard Melodies. Narrative Film Music. Bloomington \& London: Indiana University Press \& BFI Publishing.

Heldt, Guido (2013) Music and Levels of Narration in Film. Steps Across the Border. Bristol \& Chicago: Intellect.

Korganov, T. and Frolov, I. (1964) Kino i muzyka. Muzyka v dramaturgii filma. Moscow: Iskusstvo. Lawton, Anna (1992) Kinoglasnost: Soviet cinema in our time. Cambridge: Cambridge University Press.

Lexmann, Juraj (2006) Theory of Film Music (käännös Mária Stašková ja Miroslav Droždiak). Series of Slovak Academy of Sciences, volume 2. Frankfurt am Main: Peter Lang.

McMichael, Polly (2015) 'A Room-Sized Ocean'. Apartments in the Practice and Mythology of Leningrad Rock Music. Teoksessa: Risch 2015, 183-210.

Risch, William Jay (toim.) (2015) Youth and Rock in the Soviet Bloc. Youth Cultures, Music, and the State in Russian and Eastern Europe. Lanham: Lexington Books.

Ryabchikova, Natalie (2018) Kirill Serebrennikov: Summer (Leto, 2018). Review. KinoKultura - New Russian Cinema, Issue 61 (2018). <http://kinokultura.com/2018/61r-leto_NR.shtml> (Tarkistettu 2.1.2019).

Safariants, Rita (2018) Kirill Serebrennikov: Summer (Leto, 2018). Review. KinoKultura - New Russian Cinema, Issue 61 (2018). <http://kinokultura.com/2018/61r-leto_RS.shtml> (Tarkistettu 2.1.2019).

Semeljak, Maksim (2018) Uklonisty. O Viktore Tsoje i Majk Naumenko. Iskusstvo kino, no 5/6 $2018,4-7$.

Troitski, Artjom (1991) Rok v Sojuze: 60-e, 70-e, 80-e. Moscow: Iskusstvo.

Tynjanov, Juri (2001 [1927]) Kirjallisuuden evoluutiosta. Teoksessa Pekka Pesonen ja Timo Suni (toim.): Venäläinen formalismi. Antologia, Helsinki: Suomalaisen kirjallisuuden seura, 266-281.

Virtanen, Leena (2018) Kirill Serebrennikovin elokuva Kesä herättää sekä haikeutta että surua Venäjän nykymenon takia. Helsingin Sanomat 29.11.2018. <https://www.hs.fi/kulttuuri/art2000005915520.html> (Tarkistettu 8.3.2019).

Österberg, Ira (2018) What Is That Song? Aleksej Balabanov's Brother and Rock as Film Music in Russian Cinema. Akateeminen väitöskirja. Humanistinen tiedekunta, Helsingin yliopisto. Ethesis verkkojulkaisu: <http://urn.fi/URN:ISBN:978-951-51-4125-5> 